\title{
11
}

\section{How are equity markets performing in China?}

Ted Rule

Stockmarkets were first established in China in the late nineteenth century to trade the shares of companies involved in foreign trade. All treaty ports had premises where share transactions were carried out. In the early 1920s, it is estimated that China had 150 stockmarkets with the key markets in Shanghai. The 1928 China Yearbook reported that the operations of the Shanghai Gold Exchange were so vast that it was 'at times capable of influencing the destiny of other countries' currencies' (Woodhead 1929:229). Speculation was fierce and the practices ethically questionable. In 1925, the Peking Government telegraphed the Shanghai Municipal Council asking the Shanghai Consular Corps to exercise greater control over local exchanges (Woodhead 1929). A by-law that brought stock exchanges under existing by-laws was submitted unsuccessfully to special ratepayers' meetings in 1922 , 1924 and 1925 (Pott 1928). Representatives of the local Chinese community vigorously opposed the measures whilst foreign ratepayers 'manifested no interest in the matter' (Pott 1928:254).

Shanghai remained the centre of wild speculation throughout the 1930s and 1940s. In 1934, interested readers were told that 'for those who wish to "play the market", Shanghai offers a wide variety of entertainment'- as well as the London, Paris or New York Stock Exchanges, you could play local issues 'of which there are many, both bonds and shares' (Lethbridge1934:107).

When the communists entered Beijing in 1949, most of the exchanges had already closed-victims of the hyperinflation and civil unrest that had occurred during previous years. For a brief period before 1952, several exchanges reopened under the 'mixed 
economy' policy, permitting capitalists known as the 'National Bourgeoisie' to trade, however the policy had a limited lifespan. By the end of 1956, 99.6 per cent of total production was under state or 'mixed' control (State Statistical Bureau 1959) and the 'National Bourgeoisie' ceased to exist (Liu and Wu 1986).

Paradoxically, securities played a role eliminating the 'National Bourgeoisie'. Nearly RMB 4 billion $(A \$ 760,500)$ of State Treasury bonds were issued between 1950 and 1958. The 'National Bourgeoisie' had been allowed to keep 5 per cent of profits from their enterprises on condition that the majority of profits were compulsorily reinvested in state bonds (Guillermaz 1972). Thus the Party maintained the fiction of a 'mixed economy' and retained the services of managers, while redirecting profits towards state objectives.

The market system was replaced during the Great Leap Forward, where a fully developed economy and state of communism were to be achieved through class struggle. The political ascendancy of Liu Shaogi and Deng Xiaoping (1960-66) following the disasters of the Great Leap Forward introduced several semi-market measures aimed at restoring a measure of prosperity. But the political left remained strong and prevented the government from introducing market forces. Small-market measures completely disappeared with the outbreak of the Cultural Revolution in 1966.

At the end of the Cultural Revolution in the late 1970s, China was controlled by politicians that understood the inherent weaknesses in the Soviet-style economic system, and thus the need for economic reform. Much of the success of the early reforms, especially the spectacular successes in the agricultural sector, were due to the realisation that economic progress was impossible without some element of personal reward and the reintroduction of limited markets. The success of agricultural markets resonated with a body of economists with whom the modern history of the shareholding system in China begins.

\section{The birth of the shareholding system ${ }^{1}$}

In 1979, regulations were promulgated that permitted the establishment of Sinoforeign joint ventures, with the Ministry for Foreign Economic Relations and Trade (MOFERT) responsible for implementation. The regulations provided for a system based on equity shareholding. The first joint venture, Beijing Air Catering, was established in Beijing in 1979 and became the first 'shareholding' company in China since 1956.

Joint ventures rapidly became very popular amongst Chinese enterprises, including state-owned enterprises. Privileges offered to joint venture partners included favourable tax treatment, overseas travel for managers, the right to withhold foreign earnings and the ability to escape the planning net. 
The State Commission for the Restructuring of the Economic System (SCRES) approached shareholding from the perspective of economic efficiency. For political reasons, SCRES emphasised the 'experimental' nature of the system and initial experiments were confined within special economic zones. In Shenzhen, the 'Leading Committee on the Shareholding Experiment' was established in the early 1980 s to oversee the establishment of joint venture companies.

In November 1982, Shenzhen established three joint ventures—Bao'an Investment Company, Yin Hu and San He. These joint venture arrangements were not a share of ownership in the companies, as in industrial economies, but an arrangement between shares and bonds. Joint ventures guaranteed dividends and capital and permitted the refund of capital. In the early 1980s, the defining element in the value of a share was the dividend rate compared with the bank savings rate.

Outside the special economic zones, SCRES experimented with the joint venture model for merging enterprises and issuing shares. The first experiment was Beijing Tianqiao Department Store, which merged three state-owned retail department stores by assessing the net book worth and dividing it into $1 \mathrm{RMB}$ share for issue of new shares. The original three department stores made up 51 per cent of the expanded capital, which became state shares. The new shares were issued to banks-26 per cent, other institutions-19 per cent and the public. Essentially, 96 per cent of Beijing Tianqiao remained owned by the state, which owned the shareholding banks and institutions. SCRES established a new class of shares called 'legal person shares' that promoted the benefits of spreading ownership. Any entity with a business registration was treated as a legal person with limited liability. Thus, the legal person rather than the state received the benefits of ownership.

\section{Share trading}

In 1986, SCRES instituted share trading of shares, which previously had occurred only on a small scale. Shanghai was the first city in China to introduce the overthe-counter (OTC) trading of shares. The first publicly traded shares in China were in Yanzhong and Fei Le, which commenced trading over the counters of Shanghai securities companies on 9 September 1986.

The popularity of capital markets in Shanghai spread between 1986 and 1988. The Bank of Communications popularised shares and was responsible for most of the new issues, worth approximately RMB I.7 billion ( $\mathrm{A} \$ 323$ million). The bank became the first financial institution to adopt the shareholding system and similarly to other contemporary companies, the form of incorporation was non-standard and the rights and obligations of shareholders were unclear. Capital markets quickly 
developed between mid 1988 and late 1990. The first OTC trading house was the Jing'an branch of the Industrial and Commercial Bank of China. Other trading counters were located at Hai Tong Securities, the Bank of China Securities and Shanghai International Securities. The six shares listed were Yanzhong, Xiao Fei Le, Shanghai Vacuum Electron Device, Ai Shi, Shen Hua and Da Fei Le.

Trading developed simultaneously in Shenzhen during this period, and in November 1986, the Shenzhen City Government published 'Regulations Governing Experimental Corporatisation of State Owned Enterprises' to initiate a local shareholding system.

The first company to list publicly in Shenzhen was the Shenzhen Development Bank in March 1987. It became the model for future listings with clearly defined shareholders rather than the issuing of bonds by an enterprise. Shareholders could participate in management through general meetings and had rights to the distribution of profits. Liability for the company's debts was limited to the share capital. The Shenzhen Development Bank's issue of 10 million 20 RMB shares was approved in May 1987. Until the end of 1988, trading remained stagnated with no movement in prices and a total turnover of only RMB 4 million $(A \$ 760,500)$. The price/earnings ratio for the Shenzhen Development Bank was 0.2 to 0.3. The Shenzhen City Government approved a RMB 38 million ( $\mathrm{A} \$ 7.2$ million) issue by technology property company, Vanke, in December 1988 and quickly followed with the RMB 10.7 million (A\$2 million) listing of textile company Gin Tian, with an issue in February 1989.

In 1988, the Shenzhen Development Bank's profit announcement boomed at three times the previous year's figure. Investors who had expected little better than bank interest received large dividends and a bonus share issue. As word spread quickly, 'hot money' from all over China poured into the Shenzhen Stock Exchange. Turnover exploded from RMB 32.5 million (A $\$ 2$ million) for the whole year of 1988 to monthly volumes of RMB 110 million ( $\$$ \$21 million) in May 1990 and RMB 260 million ( $\$$ \$49 million) by June. The Shenzhen Development Bank's share price jumped from its issue price of $R M B 20$ ( $A$ \$3.80) to RMB 120 (A\$22.80) and market capitalisation rose from RMB 200 million (A $\$ 38$ million) in December 1989 to RMB 2 billion ( $\mathrm{A} \$ 380$ million) in December 1990. In addition, an enormous volume of capital illegally changed hands outside securities companies amongst massive crowds. Frantic trading occurred despite the lack of registration of most transactions and impossibility of verifying ownership of shares. Instead, shareholders commonly exchanged photocopies of identification cards as a form of guarantee on the title of shares. Share prices rose widely, the star performer 
was the Shenzhen Development Bank which peaked at RMB 79 (A $\$ 15)$ representing a price/earning ratio of 57, while Vanke's price/earning ration was 66 and Gin Tian's price/earning ratio was 42 .

\section{The emergence of the stock exchanges}

It became obvious that OTC trading was inadequate and the establishment of properly constituted markets was necessary. On 14 April 1989, a meeting was held to recommend the establishment of a Shenzhen Securities Exchange. A preparatory group for the Shenzhen Stock Exchange was set up under the leadership of Wang Jian, formerly a lecturer in economics at Tianjin's Nankai University and Deputy General Manager of the Shenzhen Development Bank.

In Shanghai, the People's Bank appointed Wei Wenyuan from their internal Financial Management Department as head of the preparatory group. During 1990, the Shenzhen and Shanghai preparatory groups drafted new regulations for approval by the State Council. Rivalry was fierce between the two groups for the honour of opening the first exchange.

Preparatory work for the Shanghai Exchange progressed smoothly with the support of Jiang Zemin, the former Mayor of Shanghai and the administrative and political skills of Mayor Zhu Rongji. The Shanghai Securities Exchange was officially established on 16 November 1990 within premises in the Pujiang Hotel on the north side of Suzhou Creek. The official opening ceremony was held on 19 December 1990.

Shenzhen's preparatory work progressed less smoothly because the form of regulations was reportedly constantly returned for amendments by Wang Zhen. Approval to open was only achieved after the direct intervention of Jiang Zemin. ${ }^{2}$ The Shenzhen Stock Exchange had its soft opening on 1 December 1990 in the small, modern premises on the 15th floor of the Shenzhen ITIC building. The official opening of the Shenzhen Exchange was held on 3 June 1991.

\section{Foreign participation in markets}

Foreign participation in Chinese equity markets began early. The first listed Chinese company to sell shares to foreigners was Shenzhen's Vanke in mid 1988. As part of Vanke's IPO process, Shenzhen City Government requested its Hong Kong adviser, Sun Hung Kai Securities, produce an international standard prospectus. Sun Hung Kai arranged that its Hong Kong listed associate, Tian An, subscribe for over 25 per cent ${ }^{3}$ of Vanke's capital, allowing Vanke's management to apply for joint venture status immediately. As Vanke's price continued to rise, Tian An sold 
its holding share to less than 25 per cent. Authorities were confronted with a dilemma - the joint venture arrangement was suddenly no longer a joint venture and circumstances were beyond their control. ${ }^{4}$

Many investors favoured foreign participation in the Chinese markets but opinions differed on the form of this participation. Some supported the Taiwanese model that restricted participation to a limited number of listed foreign funds, while others favoured a more direct approach. Meanwhile, the joint venture issue required resolution. Economic nationalism in Thailand and the Philippines, where stockmarkets were open to direct foreign investment, had inspired upper limits for foreign participation. China had struggled with guaranteeing minimum levels and finally established the minimum 25 per cent foreign participation requirement for joint venture arrangements, allowing enterprises to benefit from taxation and other provisions under the Joint Venture Law.

The issue of foreign participation received its first direct public airing in May 1990 at a seminar on the development of the securities market held in Shanghai under the auspices of the Stock Exchange Executive Council and the People's Bank of China. During the conference there was strong support for the proposal from the Standard Chartered Bank (Rule 1990), which identified the lack of renminbi (RMB) convertibility and privileges afforded to foreign ownership as the two main obstacles to foreign participation in Chinese markets. The proposal suggested the creation of a separate class of shares denominated in foreign currency with the subscription and all other foreign payments converted at the swap rate. Strong support from participants such as Zhou Xiaochuan, then a commissioner of SCRES, currency specialist Cao Fengqi of Peking University and Liu Hongru ensured further consideration of the proposal.

The Shenzhen Stock Exchange announced in early June 1991 that it would launch several new issues with B Share, and by September, 13 companies had received approval to issue $B$ Shares. ${ }^{5}$ Shanghai had only one approved company, an unattractive manufacturer of black and white televisions called Shanghai Vacuum Electron Limited. The company had the advantage of high-level political support from Jiang Zemin and Zhu Rongji and it became obvious that despite the merits or otherwise of listing candidates, the Shanghai Vacuum Electric would be the first company to list B Shares in Shanghai. The listing occurred on 2 February 1992. Despite the desire of involved Chinese and foreign professionals that international standards and practice be followed, political pressure to complete the deal on an unrealistic timetable meant the complete project was of poor quality. The listing documents failed to include an audit of Shanghai Vacuum Electron's 
results-in response to concerns about the quality of accounting information, Arthur Andersen produced a non-binding calculation of Vacuum's possible profits under international accounting standards in a single weekend. Underwriters then made their decisions on the basis of these quickly calculated figures. Sadly, these procedures became a precedent for the future development of the B Share market. Ad hoc, slap-dash practices and gross political interference became the guiding principles of the $B$ Share market.

The market became less rational on 2 December 1991, with the fully subscribed issue of 100,000 B Shares at RMB 420 (A $\$ 79.80)$ per share as a placement to institutions on an information memorandum. The inability to register the prospectus in Hong Kong was sidestepped. The price represented a price/earnings ratio of 80, at a discount of Vacuum's A Share price of RMB 700 (A $\$ 133$ ) (Sun Hung Kai Securities 1991).

The B Share has not been a success for the Chinese securities markets, remaining small and illiquid. Markets never became more than a device to allow foreign participation in markets to circumvent the maze of conflicting tax, currency and joint venture requirements and were viewed as a temporary measure until the yuan became convertible. This seemed more likely, paradoxically, at the opening of markets in the early 1990s than it subsequently became 11 years ago, when the People's Bank pegged the currency to the US Dollar, and even less likely during the East Asian financial crisis, when the People's Bank retreated further.

By the end of 1999, 108 companies had issued B Shares-almost all were universally poor quality companies. A study of the results of the $54 \mathrm{~B}$ Shares listed in Shanghai in 1999 revealed that only 24 companies made profits above the rate of inflation (Green and Wall 2000). Following the East Asian financial crisis, widespread concern in international financial circles about investment in East Asia meant international capital stayed away from the Chinese B Share market in droves. B Shares traded at a discount of 80-90 per cent of corresponding A Shares. There was little reason for companies to enter international markets when the necessary capital was available from the A Share market at more attractive prices.

Local capital sustained the B Share market during the period and illegal trading in B shares was ignored. Chinese citizens with foreign currency represented a large proportion of trade and ownership of B Shares. Shares were acquired on the speculation that a change in regulations to officially permit Chinese nationals to own and trade these shares, culminating in a rise in the market. By the end of 1999, the Shenzhen B Share index was languishing at 53.6 compared with a 1992 figure of 142, but by the end of 2000 the figure had risen to 85 (Shenzhen Fact Book 2003). 
In July 2001, the prayers of speculators were answered when B Share markets became open to domestic investors and the price and volume of $B$ Shares traded suddenly spiked. By the end of 2001, the Shenzhen B index had risen to 137.6, at end 2002 to 265.7 and at end 2004, 271.7 (Shenzhen Fact Book 2004). Trading volume in Shanghai and Shenzhen rose from RMB 6 billion ( $A$ \$1.1 billion) in 1998 to RMB 69 billion ( $A 13$ billion) in 2001, before settling around RMB 20 billion (A $\$ 3.8$ billion) (China Securities Regulatory Commission 2004).

Further speculation has occurred in 2005, as international investors scramble for local assets on the expectation that China will revalue the yuan (as it has done in July, Editor's note). B Shares remain a blunt instrument for raising capital in China because of the mismatch between Chinese and foreign perceptions about investment in China and foreign suspicions that Chinese regulations and supervision is inadequate. The quality of regulation has been put into sharp relief by the highly professional supervision of $\mathrm{H}$ Shares and Red Chips in Hong Kong and the generally higher quality of Chinese stocks listed in Hong Kong. Hong Kong is perceived to be a better option for foreign investors who want exposure to Chinese assets. At the same time, the enormous volume of yuan available for investment in the $A$ Share market overshadows the B Share market, given that it is cheaper capital. Between 1993 and 2004, RMB 762 billion (A $\$ 145$ billion) was raised on the Shanghai and Shenzhen markets via $A$ Shares and HK\$ 603 billion ( $A \$ 114$ billion) was raised by Chinese enterprises on the Hong Kong market (China Securities Regulatory Commission 2004). In the same period, only RMB 36 billion (A $\$ 6.8$ billion) was raised through $B$ Share issues (China Securities Regulatory Commission 2004). China's enormous foreign exchange reserves mean there is no practical shortage of foreign exchange that might encourage companies to prefer B Share issues because they can purchase foreign currency at the bank.

The weak position of the B Share was further confirmed in December 2002 with the promulgation of the Qualified Foreign Institutional Investor Law, under which qualified investors, initially Citigroup, HSBC, UBS, Nomura Securities, Deutsche Bank, Morgan Stanley, Goldman Sachs and JP Morgan, were permitted to invest in A Shares in the US $\$ 50$ to 800 million range. The foreign currency share is an anachronism that waits to take its place in history when the yuan becomes convertible.

\section{The role of Hong Kong}

Hong Kong has been a major winner, possibly the major winner, from the development of equity and other financial markets in China. After the frenzied 
development of the last 15 years, it is difficult to understand just how uninvolved the Hong Kong financial world was in Chinese finance in the mid 1980s. This is partly due to the lack of financial activity that occurred in China. In the mid 1980s, depending on the statistics consulted, the economy of Hong Kong at nominal exchange rates was between one-third and one-half the size of the total economy of the mainland.

Despite its claims to international status, in the mid 1980s Hong Kong was a medium-sized, deeply parochial market heavily weighted towards property. ${ }^{6}$ Stock exchange statistics in 1986 indicate finance was the leading sector of the market with 21.7 per cent of total market capital, but almost three-quarters was attributed to the Hong Kong and Shanghai Bank and its associate the Hang Seng Bank, accounting for 15 per cent of total market capitalisation. In 1986, 9 of the top 20 Hong Kong companies were land developers and the bulk of the market was small family companies that had listed the minimum 25 per cent of their capital but were relatively illiquid.

In 1986, 20 of the 258 companies listed in Hong Kong were classed as 'international' but these were almost all parallel listings of Malaysian and Singapore companies and rarely traded. Daily turnover was similar to that of Singapore. There were no Chinese stocks listed in Hong Kong and disgraced Hong Kong Stock Exchange Chairman Ronald Li Fook-siu was reported to have suggested to various enterprises in China that they should list assets in Hong Kong via holding companies (Rowley 1987). In March 1987, Tian An China Development Ltd ${ }^{7}$ was the first real Chinese play listed in Hong Kong, and, true to local traditions, it was a property play. It listed the foreign interests in several Chinese real estate developments, which had been injected into a Hong Kong holding company. China and Eastern Investment, a fund for Chinese investment sponsored by Baring Bros, followed shortly after.

The first listing in Hong Kong that set new parameters for future development was CP Pokphand Ltd in 1988. Assets were almost completely Chinese ${ }^{8}$ and included industrial and, for the first time in Hong Kong, agricultural assets. The first IPO after the stock exchange crash of 1987, it was attractively priced and oversubscribed 297 times. Subscriptions of HK\$27.9 billion (A $\$ 5.3$ billion) were received by the company selling shares valued at $\mathrm{HK} \$ 100$ million ( $\mathrm{A} \$ 19$ million), subsequently setting off a mania for Chinese assets. The appetite was aggressively fed by CP Pokphand's sponsor, Standard Asia, which over the next four years brought a steady stream of small manufacturers, mainly based in the Pearl River Delta, to market. As a result, the market began to move away from local property 
towards China-based manufacturing and reflected the broader trends in the Hong Kong economy. As the market began to change, Standard Chartered Asia actively prompted the raising of equity capital through Hong Kong-listed enterprises to large state enterprises and government economic regulatory bodies. In mid 1989, a large textile enterprise in Shenyang began to prepare to list in Hong Kong-the events of 4 June derailed the process. ${ }^{9}$

Prior to 1991, there was no official contact between the Hong Kong Stock Exchange and mainland financial regulators. Suggestions that Chinese enterprises should list in Hong Kong were first raised seriously in a meeting between the author and SCRES Chairman Liu Hongru in early 1991. At the same time, a group of Hong Kong brokers led by Victor Chu Lap-lik pushed for official discussions with mainland regulators. The first official meeting between the SEHK and the Financial Management Bureau of the People's Bank of China at that time the regulator of markets in China took place in Shenzhen on 5 September 1991. ${ }^{10}$

Following the meetings, the Hong Kong Stock Exchange concentrated on establishing a set of rules that would allow Chinese state enterprises to list Chinese shares governed by Chinese law directly on the Hong Kong Stock Exchange. These H Shares were established on the analogy of the B share and Sinopec, Tsingtao Brewery, Guangzhou Shipyard and Beiren Printing, were handpicked and prepared for listing.

The criteria used by the SCRES and People's Bank to select these companies illustrated the main disconnects between official thinking in China and the market reality, a contradiction that has not completely disappeared. Chinese government officials described the four companies as being amongst their best companies, however on close questioning it became clear that 'best' referred to production criteria and not necessarily to profitability or the efficient and financially productive use of funds. ${ }^{11}$ Much of the preparatory work between the Hong Kong stock exchange and Chinese officials revolved around asset productivity issues, such as resolving unfunded pension liabilities, housing, health and other welfare provisions that remained the direct responsibility of work units.

The first two issues were listed in Hong Kong on 26 July 1993 for Sinopec and Tsingtao Brewery and were followed on 6 August by Guangzhou Shipyard and Beiren Printing.

At the same time, several state-owned enterprises followed a scheme of injecting assets into Hong Kong or Bermuda shells, thus creating what are now known as the Red Chips. In 1992 and 1993, companies such as COSCO, Shougang and Oriental Metals ${ }^{12}$ were listed on the Hong Kong market. The listing of Chinese 
companies has transformed the Hong Kong sharemarket. In the early 1990s, the daily market turnover in Hong Kong was worth approximately HK $\$ 3$ billion ( $\mathrm{A} \$ 570$ million), similar to Singapore. By 2005 , the daily turnover rose to about $\mathrm{HK} \$ 15$ billion ( $\mathrm{A} \$ 2.8$ billion), while Singapore turnover remains in the $\mathrm{HK} \$ 3-4$ billion range (A $\$ 570-760$ million).

The proportion of the increased turnover attributable to trading in China stocks has risen consistently over the past 12 years. Between 1993 and 2004, total turnover on the Hong Kong Stock Exchange grew 3.3 times. Non-China turnover or the turnover of stocks not officially nominated by the Exchange as Red Chips or $\mathrm{H}$ shares grew by 2.05 times. ${ }^{13}$ During the same period, turnover in Red Chips and $\mathrm{H}$ shares grew by a massive 12.8 times. In 1993, the turnover of Chinarelated stocks was worth $\mathrm{HK} \$ 121$ billion ( $\mathrm{A} \$ 23$ billion) or 11.9 per cent of total turnover however by 1998 the turnover had grown to $\mathrm{HK} \$ 443$ billion ( $\mathrm{A} \$ 84$ billion) or 28 per cent of total turnover. In 2000 , trading was worth $\mathrm{HK} \$ 839$ billion ( $\mathrm{A} \$ 160$ billion) or 29 per cent of total turnover, and in 2004 it worth HK\$1 549 billion (A $\$ 294$ billion) or 46 per cent of turnover (Hong Kong Exchanges and Clearing 2004). In April 2005, 10 of Hong Kong's top 20 stocks by turnover were Chinese stocks, in particular China Mobile, Petro China, China Life, CNOOC, Bank of China Hong Kong, China Telecom, Yanzhou Coal, Huaneng Power and CSCL.

In terms of market capitalisation, there are now 72 listed $\mathrm{H}$ Shares with a total market capitalisation of $\mathrm{HK} \$ 445$ billion ( $\mathrm{A} \$ 84$ billion) and 83 listed Red Chips with a total market capitalisation of HK\$1 439 billion (A $\$ 273$ billion) (Hong Kong Exchanges and Clearing 2005). Market capitalisation has also grown rapidly. Chinese stocks made up 5 per cent of total market capitalisation in 1993, in 1998 the proportion had grown to 14 per cent, by 2000 it was 27 per cent and in 2004 it was 28 per cent of total market capitalisation. Six of the top 20 companies by market capitalisation, China Mobile, CNOOC, Bank of China Hong Kong, Petro China, China Unicom and China Netcom, were China-related stocks. These companies accounted for 16.5 per cent of the total market capitalisation of the Hong Kong stock exchange (Hong Kong Exchanges and Clearing 2005).

Ten of the 33 Hang Seng Index component companies are now China-related stocks, China Merchants Holdings, Denway Motors, CITIC Pacific, China Resources, China Unicom, CNOOC, China Mobile, COSCO Pacific, Bank of China Hong Kong and Lenovo Group.

The listing of Chinese companies has significantly broadened the range of industries represented on the Hong Kong board, with the appearance of completely new categories. New categories include the energy and resources sector with 
companies like CNOOC, Yanzhou Coal and Sinopec, iron and steel companies such as Chongqing Iron and Steel and Ma'anshan Iron and Steel. Petrochemical companies are now listed with Sinopec Shanghai Petrochemical, and China Petroleum and Chemical. Motor vehicles are newly represented by Denway, Brilliance China and Great Wall Automobile and the insurance sector is represented by Ping An and China Life. The utilities sector has been particularly broadened with the addition of several Chinese power generator enterprises and of a number of toll-road and airport construction companies.

Hong Kong remains one of the favourite platforms for raising funds for Chinese companies (Table 11.1).

\section{Shanghai Securities Exchange Fact Book 2004}

There is no obvious pattern in these statistics and it is difficult to predict the future for Hong Kong as a source of funds for China. The numbers are skewed by the fact that Shanghai has had an average sixty IPOs per year for the past 14 years. Hong Kong has had a very creditable performance in comparison.

For $\mathrm{H}$ Shares in particular, as Shanghai and Shenzhen price/earning ratios continue to correct, raising capital in the Hong Kong market becomes more attractive. At the peak of the bubble in China, A Shares of the same companies listed in Shanghai traded at the inflated price/earning ratios in the 40s and 50s while $\mathrm{H}$ shares, with price/earning ratios in the mid teens, were closer to their

Table 11.1 Funds raised by the market 1993-2004

\begin{tabular}{lcc}
\hline & Hong Kong (HK\$ billion) & Shanghai (yuan billion) \\
1993 & 15.0 & 9.3 \\
1994 & 13.0 & 15.0 \\
1995 & 6.6 & 5.8 \\
1996 & 19.0 & 20.2 \\
1997 & 81.0 & 47.5 \\
1998 & 17.0 & 37.7 \\
1999 & 55.0 & 48.6 \\
2000 & 294.0 & 91.4 \\
2001 & 19.0 & 95.7 \\
2002 & 52.0 & 61.4 \\
2003 & 5.0 & 56.1 \\
2004 & 26.0 & 45.7 \\
\hline
\end{tabular}

Note: $\mathrm{HK} \$ 1=¥ 1.06$

Sources: Hong Kong Exchanges and Clearing, 2005. Available online at www.hkex.com.hk/. 
Hong Kong peers. As Shanghai prices/earning ratios correct towards the 20s, the gap between A Shares and H Shares narrows and the Hong Kong market becomes correspondingly more attractive.

Companies listed in Hong Kong remain more attractive to international capital than China-listed equivalents because international capital trusts the quality of supervision and regulation in Hong Kong, particularly following the widely reported disciplinary actions against Hong Kong-listed Chinese companies. The market believes Hong Kong is immune from the corruption, petty and otherwise, the political interference and the uneven supervision which dogs the efforts of Chinese administrative bodies. International capital is correspondingly prepared to support fundraising by Hong Kong-listed companies over those of non-Hong Kong-listed companies.

Even a cursory examination shows that Red Chips have been more successful than $\mathrm{H}$ Shares on the Hong Kong market. This is not surprising given they have generally escaped the state net in various ways and have greater flexibility than large SOEs. At the most basic level, they do not have to endure the long and complicated approval measures to which $\mathrm{H}$ Shares are subject.

These trends are entirely in keeping with the general liberalisation of Chinese industry since the initiation of reforms in 1978 and are likely to continue. It should be noted, that a State Administration of Exchange Control regulation of 24 January 2005, requiring government approval for establishing businesses overseas and swapping shares with foreign companies may make the process difficult or even impossible. The author's discussions with the State Administration of Foreign Exchange in May 2005 suggest that it is an unintended consequence of currency regulations and may be subject to further revision.

\section{The development of local markets}

The Shanghai and Shenzhen equity markets must be counted as an enormous success when the overall criteria for markets are applied. After 13 years of operation, they now rank amongst the largest in the world. At the end of 2004, the two markets collectively ranked seventh in the world in number of listed companies, ahead of Euronext, Germany and Hong Kong. When separated, Shanghai was number ten in the world, ahead of Germany, Singapore and South Korea (Table 11.2).

The two Chinese domestic markets with US $\$ 452$ billion (A $\$ 603$ billion) ranked fourth in Asia after Tokyo, Hong Kong and Australia by total market capital and at the peak of the stockmarket boom, Shanghai ranked second after Tokyo.

Yet after 13 years of operations, the markets are now at a crossroad where the challenges are greater than the opportunities. The markets are victims of their 
own successes. When the markets opened in 1991 and 1992, investment in stocks was seen by the investing public as a one-way bet and the Shanghai index rose relentlessly until its peak of 2246 in 2001 . Then, equally relentlessly it began to fall and has continued to do so. By 6 June 2005, the index had dropped to 1005 and threatened to break the 1000 level (Renmin Ribao 2005b).

The reasons for the fall are complex and the political and economic repercussions are potentially wide-ranging. The simple explanation for the fall is that Chinese markets have been highly overvalued since establishment. As recently as the end of 2004, the Shanghai Exchange reported the average price/earning ratio for 2002 was 34.4 times, 36.5 times in 2003 and 24.2 times in 2004. These were the ratios after the index had fallen for three years and by the end of 2004, were a little more than one-half the peak in 2001. In comparison with markets subject to different environmental factors, the Hang Seng China-Affiliated Corporations Index had price/earning ratios of 16.2 times, 13.1 times and 18.2 times, respectively, for the same three years.

The inevitable correction was managed by a number of regulatory factors. Prior to reforms in 2001, a quota system for IPOs was rigorously enforced. The founding logic seemed to be a zero-sum game where each yuan subscribed for an IPO was another yuan which could not be subscribed to government bonds or other public purposes.

Candidates for IPO were selected by provincial and provincial-level city governments on the basis of criteria, which by definition were not necessarily commercial as selectors were not underwriting the risk. At the same time, IPO

\section{Table 11.2 World markets by number of listed companies, 2004}

\begin{tabular}{lr}
\hline Toronto & 3630 \\
NASDAQ & 3229 \\
London & 2837 \\
New York & 2293 \\
Tokyo & 2276 \\
Australia & 1582 \\
Shanghai and Shenzhen & 1379 \\
Euronext & 1333 \\
Hong Kong & 1086 \\
Shanghai & 837 \\
Germany & 759 \\
\end{tabular}

Source: Shanghai Securities Exchange, 2004. Shanghai Securities Exchange Fact Book 2004, Shanghai. 
prices were carefully controlled and kept low artificially. When average market price/earning ratios were in the $50 \mathrm{~s}$, no IPO could exceed a price/earning ratio of 20 , allegedly preventing speculation. Chinese markets have always been short of product and the amount of cash chasing the available product was enormous. RMB deposits in Chinese Banks at the end of 2004 were RMB 24,500 billion ( $A 44,657$ billion) and the ratio of M2 to GDP at 189 per cent was the highest in the world. Despite doubtlessly the best of intentions, when the demand for shares was kept artificially unsatisfied it is not surprising that the overpricing continued. While prices continued to rise, everyone was happy.

These practices led to a series of comfortable and corrupt relationships. Companies, underwriting houses and provincial governments jostled for rationed listing slots that were controlled by the CSRC. Underwriting houses controlled the allocation of shares and as an IPO was a one-way bet, it was a useful lubrication to achieve one's own objectives.

The so-called non-tradable share overhang also influenced market prices. About one-third of shares in listed companies are tradable on the exchanges and the remaining shares are owned by the state, either directly via the State Asset Supervision and Administration Commission or indirectly as legal person shares owned by other SOEs. ${ }^{14}$ The gradual removal of the state from business has been on the reform agenda for many years. Privatisation has never been an official policy and often a dirty word, yet over the past 15 years many SOEs have been sold or otherwise found their way into the hands of private and even foreign owners. Whenever possible reforms were officially raised, the prospect of the untradable two-thirds of market capital suddenly flooding the market seriously spooked investors.

Two such events took place within a short period of time in 2001 and the combination initiated the market slide. In April 2001, the IPO quota system was revoked and decisions about IPOs were vested in the CSRC and the underwriters who assumed the financial risk. On 12 June 2001, a very modest proposal was implemented to allow a limited sell-down of state shares. The purpose of the measure was to shore up the State Social Security Fund, which was experiencing liquidity problems. Under the proposal new IPOs of SOEs would sell down a block of 10 per cent of existing state shares with the proceeds going to the Social Security Fund. No existing listed company was affected by the measures sent the market into a tailspin. Between the peak of the market in April and October, the market dropped to 1600 , losing one-quarter of its value.

The reaction by the government to the crash is interesting. Share investment in China is a mass phenomenon-Shanghai alone has nearly 37 million A Share individual accounts ${ }^{15}$ (Shanghai Stock Exchange Fact Book 2004) and unhappy 
investors are a threat to political stability. The Hong Kong Economic Journal (Heung Gong Gingdzai Yatbou 2001) reported that as the market crisis deepened Zhu Rongji himself intervened and by 22 October had ordered the procedures be revoked (O’Neill 2001).

Another proposal to sell-down state shares prompted the current slump in share prices. In April 2005, the CSRC announced an 'experiment' where the state shares of four companies would be floated. Once again the proposal was modest and very generous to existing shareholders. In the case of Sany Heavy Industry, existing non-State shareholders will get three free shares plus RMB $8(A \$ 1.50)$ in cash for every State share sold (Gu 2005). Once again the market sold heavily on the news as everyone knows the meaning of 'experimental'. The markets themselves were 'experimental' long after it was practicable to reverse the 'experiment'.

However the CSRC appears to be standing firm and on 1 June CSRC Chairman Shang Fulin said, '[r]eform of the dual share system is vital to China's capital markets. It has started and the pace will not drop' (Renmin Ribao 2005a). In late July 2005 as this book was going to press, CSRC announced another 42 companies would join the 'experiment'.

Several measures have been proposed to mitigate the effects of the new policy. On 31 May, the Shenzhen Daily reported the State Council would abolish the dividend tax. In a meeting of the CSRC in early May, an extraordinary proposal was put for a state-operated fund to support the market (Renmin Ribao 2005b).

The market crash has exposed the weakness of China's securities houses. Most knowledgeable players know securities houses have been breaking the law in myriad ways for a long time. Infractions include trading on their own account using identification cards bought in rural areas, trading on the margin and using investor funds for house account trading. It is generally agreed that with the current market correction as many as half of the 130 houses are technically bankrupt. ${ }^{16}$ The most important of these to fail to date is Nanfang Securities whose liquidation was announced on 3 May 2005 (China Daily 2005). Nanfang was the fifth largest securities house and largest underwriter in Shanghai in 2004. It is reported to be RMB 10 billion ( $\$ \$ 1.9$ billion) under water. The possible repercussions of this collapse for the broader social and political peace and stability are large and it will be interesting to observe the inevitable political reaction.

\section{Regulation and supervision}

Harsh words have been spoken about the quality of regulation of domestic stockmarkets. The combination of a financial system with its roots in Stalinist 
bureaucracy and international aspirations, which focuses on the Taiwanese Ministry of Economic Affairs ${ }^{17}$ and Korean chaebols, is rarely a felicitous one. However these explanations downplay the significant progress that has been made in regulations, especially under Zhou Xiaochuan.

Zhou Xiaochuan was appointed Chairman of the CSRC in February 2000 and is probably the outstanding economic intellectual of his generation in positions of high state authority, and one of the few with a cohesive view of a market economy. He adds a fine political sense borne out of a career spent in the seat of power in Beijing and close connections to the factions that control power. His career has been spent reforming ministries, including MOFTEC, SCRES, State Administration of Exchange Control and the People's Bank. His connections with the 'Shanghai Clique' go back to his father, the Minister of the First Ministry of Machine Building Zhou Jiannan who was Jiang Zemin's boss and worked closely with Wang Daohan.

On assuming his position he quickly moved to establish the international credibility of his team. He brought back Gao Xiqing from teaching and recruited Hong Kong SFC's vice-chairman, Laura Cha, as a vice-chairman. Laura Cha was a particularly difficult acquisition; she had US citizenship, which she had to renounce to get a vice-ministerial position.

In the two years between his appointment and his promotion out of the job in November 2002, he has

- required that one-third of the boards of listed companies be made up of external and independent directors

- delisted unprofitable companies or those with a poor reporting record

- appointed inspectors and clarified their powers

- required audits by five international auditors

- prohibited the use of external borrowings to finance stock purchases

- abolished the IPO quota system.

Zhou was promoted to Governor of the People's Bank of China after the sixteenth Party Congress in 2002. Whether his successor Shang Fulin will be able to continue Zhou's work remains to be seen. He is a high-flyer and a protégé of Zhu Rongji, who first came to prominence after being appointed by Zhu in 1994 to tackle the triangular debt problem. Most people felt he was largely successful in dealing with a difficult task. When he became Governor of the Agricultural Bank in 2000, he demonstrated an ability to make tough decisions with the closing of 3,000 branches and retrenchment of 50,000 staff. This toughness is demonstrated as he continues to back the decision to sell-down state shares.

However, most observers feel that he does not have Zhou's intellectual fire powerwho does? - and there are doubts that he fully understands the implications of a 
market economy. He has created a bitter atmosphere within the commission by easing out overseas-trained staff favoured by Zhou. Gao Xiqing left very abruptly soon after Shang's arrival, and was followed some time later by Laura Cha who returned to Hong Kong. There is bitterness concerning the CSRC, where some people believe Zhou did not back his protégés sufficiently. But who will get the last laugh here? Cha has been well looked after with an appointment to Hong Kong's Executive Council and with the convergence of reform, Gao's new position as vicechairman in charge of the social welfare fund may make him one of the largest institutional investors in the market and possibly more important than Shang.

\section{Conclusion}

It has become fashionable to deride the Chinese equity markets as a 'Mickey Mouse casino'-the 'casino' accusation is a curious one. Does everybody who invests in the New York stock exchanges know exactly which way the market will move? As with so many other aspects of modern Chinese life, the markets are complex and multifaceted. Far from being a 'Mickey Mouse casino', the supervision of the markets has evolved into a system recognisable to any international investor. Supervision and regulation have become more important as the market matures. Different sections of the market have different views of risk, and as the $A, B, H$ share structure allows discrete observation of each segment, conclusions can be drawn about supervision of the market. Domestic investors remain unconcerned about the quality of Chinese supervision and may blame better supervision for the drop in the market and would rather it did not happen (Rong 2002). However international institutions have clear and negative views about the quality of supervision by Chinese officials. The differential between the $\mathrm{H}$ and $\mathrm{B}$ Share prices demonstrates that institutional investors will continue to invest in Chinese companies through Hong Kong markets.

Chinese regulators and politicians must receive the clear message - the openingup of currency markets means China will become part of the world capital market, and to be able to hold its head up high must continue the reforms initiated in 2001. As retail investors recover from the current market corrections, company information and proper regulation will become more central to investment decisions.

Hong Kong will continue to benefit as it continues with the current regulations that will secure its future as one of the world's great markets. As China continues to grow, Hong Kong may become the New York of the twenty-first century. The real challenges and opportunities available depend on whether Hong Kong can become an intermediary between the mainland and Taiwan, and integrate the equity and other markets from the three components of China. Together the four Greater 
China markets have 3,169 listed companies, only fifty fewer than NASDAQ and rank third in the world ahead of NYSE and London. More Taiwan investment money goes to the mainland than anywhere else and one million Taiwanese now live and work in China. Populations on both sides of the Taiwan Straits pay more attention to business than political visits or panda exchanges, and an integrated equity market based in Hong Kong could have much wider political and social implications. Could share trading become the ping-pong diplomacy of the twenty-first century?

In theory Shanghai should have every bit as much chance as Hong Kong to become the New York of the twenty-first century if it can overcome the difficult and fundamental problems of political interference. A significant proportion of the new middle class are share owners and a stable market is viewed by many politicians as an important part of political stability and, by extension, of maintaining power. Can a relatively closed political system respond to the imperatives of a relatively open market? Can it afford not to find a way? These are key questions that become more important with greater liberalisation. Government bodies argue public companies must behave in an open and transparent fashion. Can the question of how the government behaves be far behind? Will market reform be a catalyst for political reform?

The question of supervision also goes to the issue of minority rights. Under the current system most companies are majority state-owned and the issue is treated as redundant. It appears privatisation is again to the fore and equity markets will play a key role in the process. The process is 'experimental' but the number of experiments has, at the end of June 2005, been expanded ten times. On the record of previous 'experiments' it appears this can only increase, and means the question of minority rights must be addressed urgently.

\section{Notes}

1 The following is compiled from notes from the author's discussions between 1988 and 1992 with the following institutions: PBOC Head Office, PBOC Shanghai, PBOC Shenzhen, Shanghai City Government, Shenzhen City Government, Stock Exchange Executive Council, Hai Tong Securities, Jing'an Securities, Jun'an Securities, Shanghai Securities Exchange, Shenzhen Stock Exchange, Shanghai Vacuum Electron Device Ltd, Shenzhen Development Bank.

2 Notes from the author's discussions with members of the Shenzhen Stock Exchange in 1991.

3 The minimum level of foreign participation for joint venture status was 25 per cent. The subscription was probably illegal.

4 Notes of the author's meetings with Shenzhen Vanke, Shenzhen City Government, Shenzhen Stock Exchange and Sun Hung Kai Securities between December 1988 and June 1989. 
5 Notes from the author's meetings with members of the Shenzhen Stock Exchange in October 1991.

6 The market's property bias gave the lie to Hong Kong's other pretension-that it was a pure market-based free-enterprise economy. High property prices were largely fuelled by the public finance system of Hong Kong. Land sales finance the Hong Kong Government. Income tax is low and there are a small number of excises. The majority of the government income is raised through stamp duties, largely on land sales, and the sale of land which is released in a notably niggardly fashion. Hong Kong is one of the few places in the world where the government is proud to announce each year that land prices have risen. This has fuelled the development of artificially large land development companies.

7 Interestingly, the principles of Tian An were closely associated with both Zhao Ziyang and Milton Friedman.

8 In a nod to tradition, it included a small amount of Hong Kong property.

9 The author was involved in the process to list the Shenyang textile company on the Hong Kong Stock Exchange.

${ }_{10}$ The author arranged and was involved in the meetings preparing for the Hong Kong listing.

${ }^{11}$ Notes from meetings between the author and SCRES Chairman Liu Hongru in 1991.

${ }_{12}$ Note that the official listing dates of several Red Chips date back to the 1970s. This is a result of the use of listed shell companies for backdoor listings.

13 These statistics do not include many small industrials based around China that do not fit into either category.

14 The state has been accused acting as a monolithic owner of state shares, but this does not emphasis the local nature of SASAC intervention or the high degree of autonomy enjoyed by SOE management. The primary purpose of the SASAC is negative-to prevent the alienation of state assets and intervention is rarely made in the positive sense of securing the economic benefit for the owner, the state. Equally, intervention of a political nature can affect non-state companies every bit as much as it affects SOEs.

15 This statistic does not necessarily mean that there are 37 million individual investors. A current ID card is needed to open a trading account and for various reasons securities house have visited rural areas where ID cards are rarely needed, to purchase ID cards to open new accounts.

${ }^{16}$ Notes from discussions with current and former CSRC staff in May 2005.

${ }_{17}$ Chinese regulators have been asked why they prefer to use Taiwanese precedents as the basis for new regulations and have been intrigued at how often the answer is 'Zhonghua minzu' (Chinese race). 


\section{References}

China Daily, 2005. 'China to liquidate number 5 securities broker', 10 May 2005, accessed 14 July 2005. Available online at http//www2.chinadaily.com.cn/ English/doc/2005-05/10/content_440683.htm.

China Regulatory Securities Commission, 2004. Available online at http:// www.csrc.gov.cn/en/homepage/index_en.jsp.

Crow, C., 1933. Handbook for China, Kelly and Walsh, Shanghai.

Green, S. and Wall, D., 2000. This Little Piggy Becomes a Market, OECD, Paris. Gu, G.Z., 2005. 'China's stockmarket reforms', Asia Times Online May 24 2005, accessed week of June 6 2005. Available online at http://www.atimes.com/ atimes/China/GE24Ad03.html.

Guillermaz, J., 1972. Le Parti Communiste Chinois au Pouvoir, Payot, Paris.

Heung Gong Gingdzai Yatbou, 2001. 'Jüjung Geimaan Paaibun Kau Si, Wan Sewui', Hong Kong Economic Journal, 24 October.

Hong Kong Exchanges and Clearing. 2005. Accessed week of 6 June 6. Available online at www.hkex.com.hk/.

Liu, S. and Wu, O. (eds), 1986. 'Shehuizhuyi Jingji Jian Shi [China's socialist economy: an outline history 1949-84]', Beijing Review, Beijing.

Ministry of Foreign Economic Relations and Trade, 1979. Regulations for the Establishment of Sino-Foreign Joint Ventures, Ministry of Foreign Economic Relations and Trade, Beijing.

O'Neill, M., 2001. 'Beijing pulls plug on sales of state holdings in listed firms, easing fears of heavy dilution', South China Morning Post, October 24.

Pott, F. L., 1928. A Short History of Shanghai, Kelly and Walsh, Shanghai.

Renmin Ribao, 2005a, 'China's stock index hits eight-year lowest after new round reform starts', 2 June 2005, accessed week of 6 June 2005. Available online at http://english.people.com.cn/200506/2/eng20050602_188178.html.

_ 2005b 'Shanghai composite index falls below 1000 points', 6 June 2005, accessed week of 6 June 2005. Available online at http://english.people.com.cn/ 200506/06/eng20050606_188735.html.

Rong, F., 2002. 'Chinese investors dislike market regulation'. Available online at http://journalism.berkeley.edu/projects/greaterchina/story-stock.html.

Rowley, A., 1987. 'Asian Stock Markets', Far Eastern Economic Review, 164(47):125-56.

Rule, T., 1990. 'Zhengjuan Shichang ji qi zai Jingji Fazhanzhongde Zuoyong', Fazhan Zhengjuan Shichang Guoji Yantaohui Ziliao Huibian, Zhengjuan Jiaoyisuo Yanjiu Sheji Lianhe Ban'gongshi, Beijing. 
Shanghai Online Finance Press, 2003. 'Guowuyuan ren mian renyuan, mianqu Gao Xiqing Zhenglinhui fuzhuxi yizhi', 3 January 2003, accessed week of June 6 2005. Available online at http://finance.sina.com.cn/y/20030103/ 0830297713.shtml.

Shenzhen Fact Book, 2003 Shenzhen zheng quan jiao yi suo bian [Shenzhen Fact Book], Nankai University Press, Tianjin.

__, 2004, Shenzhen zheng quan jiao yi suo bian [Shenzhen Fact Book], Nankai University Press, Tianjin.

State Statistical Bureau, 1959. Ten Great Years: statistics of the economic and cultural achievements of the People's Republic of China, People's Publishing House of Peking, Beijing.

Sun Hung Kai Securities, 1991. Shanghai Vacuum Electron Device Limited Information Memorandum, Shanghai.

Woodhead, H.G.W. (ed), 1929 The China Yearbook 1928, Tientsin Press, Tianjin. 